УДК 82.09I

ББК $83.3(=64)$
«ЗАВЕТ» ХІІ ПАНДИТО ХАМБО-

ЛАМЫ ДАШИДОРЖИ ИТИГЭЛОВА

В КОНТЕКСТЕ БУДДИЙСКОЙ ЭСТЕТИКО-

ФИЛОСОФСКОЙ СИСТЕМЫ

\author{
(C) 2017 г. Е.Е. Балданмаксарова \\ Федеральный институт развития образования \\ Министерства образования и науки РФ, \\ Москва, Россия \\ Дата поступления статьи: I7 июля 2017 г. \\ Дата публикации: 25 декабря 2017 г. \\ DOI: IO.22455/2500-4247-20I7-2-4-270-289
}

Аннотация: Статья посвящена не исследованному в бурятском литературоведении художественному тексту, написанному известным буддийским ученым-философом XII Пандито Хамбо-ламой Дашидоржи Итигэловым. Анализируемый поэтический текст - последнее, написанное Д. Итигэловым в жанре послания произведение под названием «Завет» (1927) - адресовано людям XXI в. В 2017 г. исполняется 9о-летие достижения XII Пандито Хамбо-ламой Дашидоржи Итигэловым феноменального состояния, а го сентября - I5-летие со дня обретения Им Драгоценного Неиссякаемого Тела. Д. Итигэлов был не только лидером бурятского общества, возглавлявшим религиозную и светскую (государственную) деятельности до I9I7 г. Но, как ученый-богослов, творчески одаренная личность, он оставил богатое литературно-художественное, религиозно-философское наследие, написанное в контексте буддийской эстетико-философской системы. Безусловно, это наследие, имеющее непреходящую ценность, необходимо ввести в научный оборот, познакомить современников с этими текстами, сохранив их оригинальность, широту охвата духовных, мировоззренческих проблем, остро актуальных для современного мира.

Ключевые слова: XII Пандито Хамбо-лама Дашидоржи Итигэлов, буддийская философия, литературный канон, индо-тибето-монголо-бурятские литературные связи.

Информация об авторе: Елизавета Ешиевна Балданмаксарова - доктор филологических наук, главный научный сотрудник, Федеральный институт развития образования Министерства образования и науки РФ, ул. Черняховского, д. 9, стр. I, г25319 г. Москва, Россия.

E-mail: liza.bur@mail.ru 


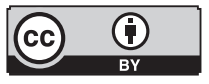

This is an open access article distributed under the Creative Commons Attribution 4.0 International (CC BY 4.0)

\section{"THE TESTAMENT" OF XII PANDITO HAMBO-LAMA DASHIDORZHI ITHEGELOV IN THE CONTEXT OF BUDDHIST PHILOSOPHY}

\author{
(C) 20I7. E.E. Baldanmaksarova \\ Federal Institute for Educational Development Ministry \\ of Education and Science of the Russian Federation, \\ Moscow, Russia \\ Received: July I7, 2017 \\ Date of publication: December 25, 2017
}

\begin{abstract}
The article deals with a hitherto unexamined literary text written by a famous Buddhist philosopher and scientist XII Pandito Hambo-Lama Dashidorzhi Itigelov. This text is the last poem by D. Itigelov entitled “The Testament” (1927) written in the genre of the epistle and addressed to the people of the $2 \mathrm{I}^{\text {st }}$ century. 2017 is a year of the 9oth anniversary of the phenomenal state achieved by the philosopher; on September Io, Buryat people celebrate the I5th anniversary of his acquisition of the Precious Inexhaustible Body. Not only was D. Itigelov a leader of the Buryat society who headed its religious and secular (state) activity until I9I7, he also was an educated theologian and a gifted writer who left rich literary, religious, and philosophical heritage relevant in the context of the Buddhist aesthetics and philosophy. This essay calls for the necessity to make this heritage available to public by stressing its originality and relevance for contemporary society.

Keywords: XII Pandito Hambo-Lama Dashidorzhi Itigelov, Buddhist philosophy, literary canon, Indo-Tibeto-Mongolian-Buryat literary connections.

Information about the author: Elizaveta E. Baldanmaksarova, DSc in Philology, Director of research, Federal Institute for the Education Development at the Ministry of Education and Science of the Russian Federation, Chernyakhovskogo 9/I, I253I9 Moscow, Russia.

E-mail: liza.bur@mail.ru
\end{abstract}


Обращение к творческому наследию XII Пандито Хамбо-ламы² Дашидоржи Итигэлова 3 в в частности, к его «Завету» (Захяа) позволяет рассмотреть данное поэтическое произведение в контексте проблематики «текст и традиция».

Сразу отметим: «Завет» Д. Итигэлова представляет собой классический текст буддийского содержания, соответствующий литературному канону, сложившемуся в индо-тибето-монголо-бурятской эстетической традиции. Безусловно, канон - это вербальная репрезентация традиции. Любой классический старомонгольский текст, или текст, написанный на тибетском языке бурятскими учеными ламами, найденный и введенный в

I Пандит (санскр.) - ученый муж, мудрец; титул, применяемый к Хамбо-ламам в России. Как пишет Д.Г. Чимитдоржин, «22 июня I764 года за № 6го по ходатайству нойонов селенгинских родов бригадиру Якоби вышел указ Пограничной канцелярии об утверждении Дамба Даржа Заяева в должности “Главного Пандито Хамбо-ламы всех буддистов, обитающих на южной стороне Байкала”. С этого момента официально утвержден статус главы буддистов Хамбо-ламы, заложивший институт Хамбо лам. Статус Пандито Хамбо-ламы подтвержден самой императрицей Екатериной II. Дамба Даржа Заяев “удостоился милостивого внимания. Государыня просила Дзаяева указать, какой награды он желает со стороны ея Величества. Дзаяев просил наградить титулом Пандито Хамбы, что и было дано” [І9, с. 6І8]. См. об этом: [І9, с. 14-15].

2 Хамбо-лама - титул Верховного ламы Буддийского Духовенства Восточной Сибири (1764-I932 гг.; с 1946 - по настоящее время); официально под единым управлением Пандито Хамбо-ламы находилась вся религиозная и светская (государственная) деятельность в бурятском обществе с I764 г. XVIII в. до I9I7 г. XX в.; лама, тиб., гуру, санскр. - духовный наставник, мастер, дословно: «весомый», что призвано символизировать его существенные познания в буддийском учении; служитель буддийского духовенства.

3 Дашидоржи Итигэлов (I852-I927) - XII Пандито Хамбо-лама Буддийского Духовенства Восточной Сибири (г9Іі-I9I7). См. о нем: [8]. 
научный оборот в настоящее время, взыскует прочтения, перевода, комментирования, изучения, с привлечением имеющихся в гуманитарной науке методологических подходов.

В литературоведческой науке известны так называемый «метод медленного прочтения классики», герменевтический аспект изучения текста, обращение к которым приносит свои плодотворные результаты. Классическая литература буддийского направления, созданная на индийской ${ }^{4}$, тибетской ${ }^{5}$ почве, а затем и на бурят-монгольской на тибетском языке или на старомонгольской письменности, функционировавшая в рамках живой традищии, рассматривалась как эталон и образец, ибо основывалась на вневременных категориях. «Мы называем нечто классическим, - отмечает Г.-Г. Гадамер, сознавая его прочность и постоянство, его неотчуждаемое, независимое от временных обстоятельств значение, - нечто вроде вневременного настоящего, современного любой эпохе. <..> То, что называется “классическим”, прежде всего не нуждается в преодолении исторической дистанции - оно само, в постоянном опосредовании, осуществляет это преодоление» [II, с. 342-343].

Изучение «Завета» Д. Итигэлова осознается нами как способ сохранения и передачи основных философских, эстетических и нравственных буддийских констант. Классический канон, нашедший свое отражение еще в древнеиндийском трактате по теории поэзии «Кавьядарша» (Зохист аялгууны толь) Дандина [4, с. 89-94], в рамках которого создает свое произведение Д. Итигэлов, - это своеобразная форма традиции, которая благодаря четкости, стройности формы и следованию выработанной веками эстетической платформе, художественно-изобразительным средствам осуществляет исполнение потенциальных возможностей, заложенных в самом произведении. Индо-тибетский эстетический канон действует как культурный код, как культурная память, в силу чего выступает как почва для нового творчества в существующей системе ценностей. Поэтому можно констатировать, что «Завет» Д. Итигэлова имеет прочную эстетическую и аксиологическую основу, связанную с буддийской философией.

\footnotetext{
4 В качестве примера можно сослаться на канонические тексты, созданные в Индии во II и VIII вв. Это «Сухрил-лекха» (Дружественное послание) Нагарджуны, санскритский оригинал которого не сохранился, известен по переводу на тибетский язык; философская поэма Шантидевы «Бодхичарьясаттва-аватара» (Путь Бодхисаттвы). См. об этом: [2, c. $136-164 ; 20]$.

5 Гьялсе Тхогме Зангпо. «37 практик Бодхисаттвы». См. об этом: [г2].
} 
Несколько слов о личности Дашидоржи Итигэлова, который совершил при жизни и после жизни уникальный поступок, оцениваемый нами, современниками, как «явление», как «чудо», вошедший в мировую историю под названием «феномен Итигэлова». Это связано с удивительным событием, произошедшим в начале XXI в. в Республике Бурятия Российской Федерации. Іо сентября 2002 г.: на поверхность земли был поднят кедровый короб с телом Д. Итигэлова.

I5 июня I927 г. Дашидоржи Итигэлов принял решение уйти из этого мира и попросил своих учеников, входя в состояние шамадхи, начать чтение молитвы для усопших и провести специальный обрядовый ритуал предания его тела земле и предсказал срок своего возвращения. Специалисты Российского центра судмедэкспертизы Минздрава РФ под руководством профессора В.Н. Звягина провели исследование образцов тела Итигэлова и пришли к выводу, что бальзамация или мумификация тела не применялись. В. Звягин в одном из интервью сказал: «Состояние тканей таково, что оно вполне соответствует прижизненной характеристике. Нам неизвестны случаи такой сохранности, которое имеет тело Итигэлова. Это некая научная загадка» [8, с. I07]. Со дня возвращения Драгоценного Неиссякаемого Тела (Эрдэни Мунхэ Бэе, бурят.) Хамбо-ламы Д. Итигэлова прошло пятнадцать лет, и эта загадка еще не разгадана. Думается, сегодня можно только констатировать: Итигэлов продемонстрировал миру, что есть пути преодоления двойственности человеческой природы и полного очищения тела, речи и ума человека от загрязнений и омраченности.

«Завет» Д. Итигэлова написан на классическом старомонгольском языке с вертикальным графическим письмом в жанре послания. С 30-х гг. $\mathrm{XX}$ в. рукопись этого произведения хранилась в Барге во Внутренней Монголии Китая, куда эмигрировала часть хоринских бурят. Гэлэг Балбар-лама, служивший в Шэнэхэнском дацане, вернувшись из эмиграции в Бурятию, передал ее в Иволгинский дацан в 1996 г.

Обращение к структурообразующим доминантам текста Итигэлова позволяет выделить три крупные части, логически вытекающие одна из другой. В первой части текста автор лаконично и в то же время содержательно объемно излагает свой Путь: как шло духовное развитие его личности, начиная с безначальных времен до настоящего времени, т. е. до 1927 г., когда создавалось это произведение: 
Лама, искоренивший стремление к сансарному бытию силой благословения Трех Драгоценностей,

Сумевший с постоянством безопасно преобразовать Ум, Объединивший в одно главное, встречающиеся десять, Богатый накопленными добродетелями с безначальных времен, со времен молодого друга,

Преобразовавший свои пять скандх в драгоценность, подобной горе Сумеру. (здесь и далее перевод мой. - Е.Б.' $)$

В первой строке автор констатирует, что ему, ламе, удалось искоренить стремление к сансарному7 бытию силой благословения Трех Драгоценностей ${ }^{8}$, т. е. он достиг состояния «пробуждения» от сна сансарического существования к истинному знанию и реальности благодаря своему йогическому опыту и сумел еще при жизни осознанно преодолеть цикличность бытия и выйти за его пределы. Здесь закладывается мысль о вере, что именно она, вера в Будду, Дхарму и Сангху, а также сила их благословения может помочь человеку, вступившему на Путь духовного совершенствования, вырваться из уз сансары, где он кружится под влиянием негативной кармы и изъянов сознания в нескончаемой череде рождения, смерти и нового рождения, странствуя из жизни в жизнь. Это первый аспект Пути к просветлению ради счастья всех существ, на который встал Д. Итигэлов. И этот аспект Пути можно обозначить понятием, известным в буддизме как отречение.

6 При переводе «Завета» (Захяа) Д. Итигэлова мы придерживались сложившейся традиции перевода буддийских текстов «неукоснительно следовать его смыслу, а не букве, т. е. нельзя искажать значение ради стихотворной метрики и художественной формы». См. об этом: [2, с. 322].

7 Сансара - безначальное циклическое бытие или круговерть; считается, что сансара делится на три мира: мир желаний, мир форм и мир без форм. Существа мира желаний относятся к шести категориям, или шести мирам. Психофизические совокупности (санскр. скандхи) этих шести живых существ кружат под влиянием негативной кармы и изъянов сознания в нескончаемой череде рождения, смерти и нового рождения, странствуя из жизни в жизнь в состояниях богов, полубогов (асуров), людей, животных, ненасытных духов (претов), обитателей ада. Фундаментальной характеристикой сансарного существования является страдание, непостоянство, бессущностность, загрязненность.

8 Три Драгоценности - одно из названий буддизма, под которыми понимаются три объекта буддийского прибежища: Будда (Просветленный), Дхарма (Его Учение) и Сангха (община Его последователей). 
Далее он пишет о том, что ему удалось безопасно преобразовать свой Ум, постоянно применяя буддийские практики. Ведь преображение мышления, трансформация сознания, работа по воспитанию ума относится к одной из ключевых категорий буддийской философии и представляет собой весьма широкое понятие. Для примера можно сослаться на фундаментальный труд «Этапы пути пробуждения» (Лам-рим) Чже Цонкапы. Существует особая духовная традиция, передающаяся в живой форме от учителя к ученику. К практикам высшей личности по безопасному преобразованию Ума относятся семичленный причинно-следственный метод зарождения бодхисаттовской ${ }^{\text {го }}$ мысли, практики «замены себя на других», «принятия и отдачи», методы аналитической медитации, в частности «випашьяна» ${ }^{\text {II }}$ и др. По существу, преображение мышления - это метод, направленный на взращивание драгоценной мысли бодхичитты ${ }^{{ }^{2}}$ и является грозным оружием против злейшего врага человека - привязанности к индивидуальному Я. Таким образом, главным смысловым содержанием понятия преобразования Ума является подавление заботы о себе, взращивание бодхичитты Ума, устремленного к пробуждению ради блага всех шести живых существ ${ }^{\mathrm{I3}}$,

9 Чже Цонкапа (1357-I4I9) - основатель одной из главных четырех буддийской школ гелугпа (ньингма, сакья, кагью) в Тибете. В среде буддистов есть мнение, что трактат Цонкапы «Дэмбрэл Додбо» о пустотности явлений стал одним из основополагающих трудов, лежащих в основе достижения Итигэловым феноменального состояния.

го Бодхисаттва (санскр.) - тот, кто (sattva) посвятил себя духовному пути и обладает альтруистической мыслью бодхичитты и мудростью, постигающей пустотность; тот, кто стремится к достижению высшей цели духовных исканий - Пробуждению (Bodhi - cocтояние, лишенное любых изъянов и наделенное всеми достоинствами) во имя счастья всех живых существ, не теряя отваги; тот, кто стремится к окончательному выходу из круговорота сансары в нирвану.

II Випашьяна - (санскр., букв.: «Высшее проникновение») - это метод аналитического исследования основных закономерных явлений сансары (непостоянства, страдания, бессамостности), помогающий постижению истинной природы всего сущего - пустоты. Випашьяна - один из двух факторов (второй - шаматха, используемый в качестве предварительной практики), необходимых для достижения пробуждения.

I2 Бодхичитта (санскр.) - одно из ключевых категорий буддизма, в основе которой устремленность к достижению просветления, движимая великой любовью и великим состраданием, ради освобождения всех шести живых существ от страданий и обретения ими счастья, т. е. полной свободы от круговерти в сансаре. Зарождение бодхичитты служит отправной точкой для духовного пути и подразделяется на высшую и относительную.

I3 Шесть живых существ - по буддийской космологии существует три плана сансарного бытия, один из них - мир страстей, или мир желаний - населён шестью классами живых существ: боги, полубоги (асуры), люди, животные, ненасытные духи (преты), обитатели ада. 
обитающих в сансаре. Это второй ключевой аспект Пути Бодхисаттв, выбранный Д. Итигэловым.

Третья строка первой части данного произведения при всей своей внешней сжатости и краткости («объединивший в одно главное, встречающиеся десять» $\left.{ }^{14}\right)$ наиболее емко и объемно выражает все те совершенные способности (сиддхи, санскр.), к которым он пришел, выполняя шаг за шагом практики бодхисаттв, переходя из одной жизни в другую. В наиболее концентрированном виде они были проявлены им именно в этом теле, в теле Итигэлова еще при его жизни вплоть до 1927 г. ${ }^{15}$ Известно, что Хамбо-лама Д. Итигэлов является двенадцатым в линии перерождений святых людей Индии, Тибета и Бурятии ${ }^{16}$, донесший благословение и духовные достижения этих великих Учителей.

Рукопись о линии преемственности Дашидоржи Итигэлова под названием «Поклонение совершенной линии преемственности высоких перерождений Учителя» (Дээдэ хубилгаанай бэрхэ ябасанай дээдэ түгэсын түүхэдэ зальбарал, бурят.), написанная на тибетском языке, была найдена в Иволгинском дацане в марте 2005 г. Далее выяснилось, что впервые

I4 Десять встречающиеся - имеется в виду известные в буддизме десять стадий духовного роста, или десять ступеней, которые проходит бодхисаттва на пути к пробуждению: первая соответствует началу пути видения, со второй по десятый - это последовательные ступени пути медитации. Здесь также имеется в виду десять благ, способствующие духовной жизни. Они подразделяются на пять объективных (приход Будды, преподавание Дхармы, процветание Дхармы, приобщение последователей к Дхарме, доброжелательное отношение к духовным лицам и практикующим) и пять субъективных (обретение человеческого тела; рождение в стране, где есть Дхарма; обладание полноценными органами чувств; не совершение злодеяний; вера в Дхарму) благ или качеств бодхисаттв, которыми сумел овладеть Д. Итигэлов («объединил в одно») и умело пользовался ими.

I5 До сих пор бытуют в народе многочисленные устные рассказы о тех сиддхах, которые Итигэлов проявлял еще при жизни. Например, о его удивительных способностях укрощать время и пространство, о его умении проходить, сидя в запряженной телеге, по глади Гусиного озера как по обычной дороге и др., в детстве я много раз слышала от своих земляков, от своей бабушки, которая знала об этом не понаслышке, её муж, мой дед, был ламой, репрессирован и расстрелян в Чите в 1938 г., реабилитирован в 1958 г.

I6 Из содержания данного произведения известно о том, что Д. Итигэлов, будучи в прошлой жизни Д.Д. Заяевым, во время учебы в Тибете, обращается к Далай-ламе и Панчен-ламе с просьбой рассказать ему о его прошлых перерождениях. Далай-лама и Панчен-лама признали, что он является великим перерожденцем, и посоветовали обратиться к Махакале - Защитнику и Хранителю Дхармы. Когда, возвратившись из Тибета на родину, Хамбо-лама Д.Д. Заяев с ламами и учениками в местности Ранжун Маани преподнес мандалу Махакале, Тот в ответ поведал историю о десяти его предыдущих воплощениях: пять в Индии, пять в Тибете. См. об этом: [8, с. 40]. 
рукопись была обнаружена в I973 г. при XIX Пандито Хамбо-ламе Жамбал-Доржи Гомбоеве. По его просьбе было изготовлено новое клише, и по нему данная рукопись была напечатана в Агинском дацане Забайкальского края. Считается, что автором данного стихотворного произведения является сам Д. Итигэлов, знавший все свои одиннадцать предыдущих жизней: пять в Индии, пять в Тибете и одна в Бурятии.

По буддийским воззрениям не только устранение омраченности ума, устремленность к пробуждению ради блага всех живых существ, овладение универсальными средствами, как четыре благородные истины ${ }^{17}$ и шесть парамит $^{18}$, но еще накопление благих деяний, благих качеств личности приводит к достижению святости, способствующей выходу из сансарного круга. И в четвертой строке автор прямо указывает, что благие деяния он начал совершать «с безначальных времен», особенно активно «со времен молодого друга». Если Будда Шакьямуни является IV Буддой благого эона (или кальпы - время прихода Будд в мир людей), то период Его времени рассматривается как период зрелости. Соответственно, предшествующий период III Будды - Будды Кашьяпы является временем молодости или временем молодого друга. Это Д. Итигэлов изложил в поэтической форме в третьей строфе другого своего произведения «Поклонение совершенной линии преемственности высоких перерождений Учителя», упомянутого выше.

В заключительной, пятой строке первой части говорится о том, что он, Итигэлов, сумел преобразовать свои пять скандх, т. е. свои психофизические совокупности тела, речи и ума, которые постоянно находятся в процессе изменения и преобразования в драгоценность, подобной вечно незыблемой горе Сумеру ${ }^{19}$, представляющей по понятиям буддийской космологии, центр Вселенной.

I7 Четыре благородные истины - это основа для всех направлений буддизма, фундамент буддийского учения, суть которого заключается в том, что есть истина о страдании, которую нужно распознать; есть истина о причине страдания, которую нужно отринуть; есть истина о пресечении страдания; есть истина пути, ведущая к уходу от страданий. Это учение было даровано Буддой Шакьямуни при первом повороте Колеса Дхармы.

I8 Шесть парамит (букв.: «То, что переводит на другой берег») - для того, чтобы практиковать путь Бодхисаттв существует много различных хороших методов. Однако есть эффективное средство, именуемое шесть парамит, к которым относятся: щедрость, осмысленное поведение, терпение, радостное усердие, медитация и мудрость. Первые пять парамит - это структура, которой придерживается практикующий, а мудрость - результат.

I9 Сумеру (Меру, или Благая Меру) - центр нижней сферы буддийской космологии. 
Во второй части произведения, состоящей из четверостишия, Д. Итигэлов предсказывает свое будущее. Силой медитации и чтением специальных буддийских текстов в 1927 г. он добровольно остановил (или приостановил) свое сердце и функционирование жизненных процессов ор-

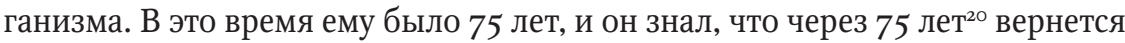
в новом качестве. Д. Итигэлов в поэтической форме подробно описывает свое состояние, в котором он находится с сентября 2002 г. по настоящее время, когда его извлекли из места медитации, согласно его устному завещанию. Он пишет об этом как бы со стороны, дистанцируясь, обращаясь к себе сегодняшнему на «Вы». Примечательно, что эта часть написана как благопожелание себе в будущем, каким бы он хотел себя видеть. Вернее, наверное, будет сказать, знал, что именно таким он и будет при возвращении в новое для него время в форме Драгоценного Неиссякаемого Тела.

Пропитавшееся Драгоценным Учением Ваше тело

в умиротворенном покое,

В эту опасную, смутную эпоху упадка не пристает к Вам болотная грязь.

Подобно цветку, принадлежите Родине, где выросли, как пять скандх - растущему дереву,

И нет Вам вреда от препятствующих пяти желаний, словно от инея и града,

в Вас совершенная чистота.

В первой строке второй части Итигэлов свидетельствует, что ему удалось преобразовать не только свои ум и сознание, но и свое тело, которое в достаточной степени пропиталось Драгоценным Учением, чтобы пребывать в состоянии умиротворённого покоя ${ }^{21}$ продолжительное вре-

20 Число 75 повторяется четыре раза: I Пандито Хамбо-лама Дамба-Даржа Заяев (по линии преемственности Д. Итигэлова он одиннадцатый) прожил 75 лет. Через 75 лет после Его ухода родился Д. Итигэлов, который прожил 75 лет и возвратился в форме Драгоценного Нетленного Тела через 75 лет. XXIV Пандито Хамбо-лама Дамба Аюшеев, возглавляющий ныне Традиционную буддийскую Сангху России, связывает число 75 с Махакалой, с Его личной свитой, которых 75. Каждый из них под руководством Махакалы оберегал Хамбо-лам Заяева и Итигэлова и помогал им на каждом году жизни. Об особой связи Хамбо-ламы Дамба-Даржа Заяева с Махакалой известно из автобиографической книги, написанной Хамбо-ламой Д. Итигэловым. См. об этом: [17, с. 124-І25].

2I Умиротворенный покой (умиротворённое пребывание, безмятежность), или шаматха (санскр.) - это метод успокоения ума достижением состояния непрерывной сосредоточенно- 
мя незыблемо и стабильно, без особых усилий столько, сколько необходимо.

Итигэлов предвидел, что время его возвращения совпадет со временем упадка в обществе, когда все материальное окажется намного важнее духовного, ложно ориентируя человечество и провоцируя опасные конфликты, вызванные стремлением к обладанию ошибочно понятыми ценностями, которые, как болото, все больше и больше затягивают людей, погружая их только в один мир - мир материальный. Приход Итигэлова именно в это опасное, смутное время упадка - возможность показать миру своим живым примером бесперспективность такого развития. Показать, что есть другие пути, выбрав которые можно освободиться от «болотной грязи» и она больше не пристанет. Здесь автор апеллирует к одному из основных буддийских символов - лотосу, который вырастает из болотной грязи совершенно чистым и прекрасным.

В третьей строке говорится о важности для человека принадлежности к Родине: человек, как цветок, должен украшать ту землю, где вырос, т. е. быть ей полезным «как пять скандх ${ }^{22}$ - растущему дереву». Здесь проводится параллель: человек - дерево. Пять скандх человека сравниваются с растущим деревом, ибо психофизические составляющие человека непрерывно изменяются, подобно растущему дереву. Дерево корнями уходит в землю, а кроной - в небеса, соединяя верх и низ, подобно человеку: в этом автор видит их идентичность.

Заключительную строку четверостишия нужно понимать так, что он, Итигэлов, уже не будет испытывать разных эмоций от пяти желаний², порождаемых пятью органами чувств (глаза, уши, нос, язык, кожа), которые препятствуют достижению совершенного просветления и чистоты, ибо у него нет в этом необходимости, так как он сумел достичь того состояния, когда они ему уже не мешают. Это состояние сегодня мы можем смело назвать святостью.

сти сознания на избранном объекте естественно, беспрепятственно и длительно, без усилий со стороны медитирующего.

22 Пять скандх (санскр., в досл. переводе означает «куча», «масса») - это психофизические совокупности тела, речи и ума человека. К пяти скандхам или к первоэлементам относятся: І) телесная форма, 2) чувства или эмоции, 3) восприятие или различающие мысли, 4) волевые акты и энергетические импульсы, ответственные как за поддержание единства, так и за динамику изменения человека во времени и пространстве, 5) сознание.

23 Пять желаний - это желания, порождаемые с помощью пяти органов чувств, таких как глаза, уши, нос, язык, кожа. 
Третья часть этого стихотворного произведения - наиболее крупная по объему - состоит из обращения ко всему буддийскому сообществу. В нем содержатся ценные авторские размышления об основных философских категориях буддийского учения, а также о том, чего он достиг посредством слушания, изучения, обдумывания философских основ буддизма в процессе анализа и медитации в течение всей своей жизни, опираясь на собственное понимание и опыт.

Воспользуясь случаем, обдумываемое превращая в знак, скажем так:

«Найдя трудно добываемую даже для ученого человека, дарующую свободу, святыню,

Встретив трудно постигаемую Драгоценность Учения Будды,

Преодолев трудности встречи с Ваджрадхарой с помощью завоеваний Ламы,

И, обманываясь деяниями бытия, основанного на ложных воззрениях, Без сожаления проживаем земную жизнь, и в конце ее,

Подгоняемые красной энергией, накопленной в предыдущих рождениях, Ведомые хозяином смерти, приносящим несчастье,

В час отхода в мир иной отправляемся совершенно одинокими -

Без близких, любимых, накопленных богатств - ведь

Все они, оставаясь на этой земле, не смогут последовать за тобой.

От неразумно собранных материальных благ

Нет пользы, они отравляют как яд!» -

Так издревле было изречено всеми Высочайшими Буддами.

Начав осознавать с настоящего времени, что в сансаре по сути ничего стабильного и прочного,

Усердствуйте в овладении безопасной практикой Десяти белых благих деяний!

Пока я жив, обращаюсь к вам с прощальным словом Наказа и нет у меня большего желания.

Итигэлов пишет, что можно прийти к вере в Драгоценность Учения Будды, можно обрести наивысшую свободу, имея в виду конечную 
цель буддиста - нирвану, но осознает трудность его постижения даже для ученого человека. Встретиться с Ваджрадхарой ${ }^{24}$ трудно, но она, эта встреча, оказывается возможной с помощью Его, Ламы, завоеваний. Известно, что у Хамбо-ламы Итигэлова существовала особая мистическая связь с Ваджрадхарой (Очирдари, монг.), поэтому для практикующих буддизм в наше время возможна встреча с Ним с помощью тех высших духовных реализаций, которые были достигнуты Итигэловым, получившим от Него напрямую эзотерические знания. Итигэлов, как один из наиболее выдающихся последователей и продолжателей наследия мысли и духа величайших древнеиндийских и тибетских Учителей, возродился в XXI в. в новом качестве, чтобы помочь своим Словом и Делом яснее осознать и постичь суть Учения Будды, а на его основе - реальную картину мира и бытия.

Строка «и, обманываясь деяниями бытия, основанного на ложных воззрениях...» крайне важна для понимания концептуальных положений буддийской философии. Поскольку в основе сансарического существования - непостоянство, страдание, бессущностность, омраченность ума, то человек по большей части воспринимает вещи и явления не так, как они существуют на самом деле. И человек зачастую оказывается во власти неверных представлений и по неведению цепляется за свое ошибочное восприятие, ибо довольствуется поверхностным пониманием жизненных явлений и еще в достаточной степени не обладает той мудростью, которая выражается в способности видеть реальность такой, какой она является в действительности. Об этом бдительно напоминает и от этого остерегает Д. Итигэлов.

\footnotetext{
24 Ваджрадхара - (Очирдари, монг., бурят.; Дорджечан, тиб.) - форма, которую принял Будда Шакьямуни, давая миру учение тантры; коренной Гуру, высшее существо в иерархии всех существ, Адибудда (персонификация Изначального, Абсолютно чистого, Всеблагого и Всеведующего принципа сознания в ваджраяне наиболее стремительной «колеснице» буддизма, способной привести практикующего к достижению просветления уже в этой жизни) некоторых высших тантр (тантры - тайное учение Будды; текст буддийского канона, содержащий подобные учения и практики) школы гелугпа, например, Калачакратантра, Чакрасамваратантра. Известно, что Д. Итигэлов отмечал свою особую связь с Очирдари, считал его духовным наставником, от которого он получает напрямую Его Учение. Художник, мастер буддийской живописи танка Александр Кочаров не раз высказывал мысль, что в иконографии Ваджраяны первостепенную роль играет образ Ваджрадхары, от которого произошли все тантрические методы Спасения и практика которого является завершающей в реализации просветленной природы Будды.
} 
В фундаментальном труде «Бодхичарья-аватара» Шантидевы ${ }^{25}$ приводятся слова самого Будды Шакьямуни о том, чтобы «не принимали на веру учение только потому, что так сказал Будда, а как золотых дел мастер проверяли его, подвергая горению, рассечению и трению», т. е. здесь говорится о том, что необходимо исследовать, анализировать, приводить логические доводы, опираясь на опыт. Вот те Четыре опоры, которые могут оградить человека от ложных воззрений:

Не полагайтесь на человека, полагайтесь на учение.

Не полагайтесь на слова учения, полагайтесь на их смысл.

Полагайтесь не на относительный смысл, а на абсолютный.

Полагайтесь не на простое интеллектуальное понимание,

а на высшую мудрость.

Таков разумный подход к постижению учения Будды.

$$
\text { [I3, c. 2I] }
$$

К базовым буддийским идеологемам относится понятие кармы, которое не мог, естественно, обойти Д. Итигэлов в своем обращении. Согласно этой идее эмпирическое существование человека в миру, каждый его шаг телесный, речевой или умственный - регулируется законом причинно-следственных отношений, распространенным на морально-нравственную сферу и сферу психики. Идея неизбежности возмездия за проступки или воздаяния за добродетель - краеугольный камень буддийской философии.

Слово «карма» означает «дело», «действие» вообще, причем не только физическое, но также вербальное и ментальное (психический акт). Любое из этих действий по шкале универсального закона кармы приносит результат, присовокупляясь к действиям, совершенным в течение всей жизни. Их итог определит благие и неблагие формы рождения и основные параметры следующей жизни, которая с неизбежностью сменяет жизнь закончившуюся. Итигэлов определяет их в виде красной энергии ${ }^{26}$, которая,

25 Шантидева - выдающийся буддийский подвижник, мыслитель и поэт I пол. VIII в. Он входит в число семнадцати пандит (мудрецов) древнеиндийского университета Наланда.

26 Красная энергия - из существующих шести типов сознания (глаза, уха, носа, языка, тела, ментального сознания) именно ментальное сознание переходит из жизни в жизнь, реинкарнируясь. Пять сознаний органов чувств растворяются и исчезают в момент смерти. Поток же ментального сознания в виде красной энергии продолжается, надёжно храня в 
накапливаясь и надежно храня в себе все отпечатки, оставленные человеком мыслями, поступками в предыдущих рождениях, сопровождает его из одной жизни в другую. Итигэлов напоминает: всеми Высочайшими Буддами было изречено, что именно благие и неблагие мысли, слова, поступки людей имеют силу и значение, а не материальные блага, которые, если они были собраны неразумно, могут отравлять, как яд.

Непостоянство - одно из фундаментальных характеристик сансарного существования, поэтому в сансаре не может быть «ничего стабильного и прочного». На этом постулате акцентирует свое внимание Итигэлов в конце произведения именно потому, что оно тесно связано с воззрением, постигающим пустотность. Это третий ключевой аспект Пути к просветлению Д. Итигэлова, тесно связанный с учением буддийской философии о пустоте ${ }^{27}$.

Основой его является теория взаимозависимого возникновения, согласно которой любое явление (объект) возникает взаимозависимо, на что-то опираясь. В силу чего оно по своей изначальной природе пусто, то есть не имеет собственного сущностного существования. Поэтому все, что возникло взаимозависимо, является пустотным или пустым от собственной природы. Таким образом, пустотность и взаимозависимость (взаимосвязанность) - это синонимы. Все явления взаимосвязаны, взаимозависимы, и если нет целостной картины мира, то она будет далекой от истины, от подлинной природы вещей, т. е. эти объекты или явления будут лишены абсолютной реальности. Понятие пустоты устраняет, с одной стороны, крайности нигилизма (полного отрицания), а с другой - этернализма (крайности утверждения постоянства), актуализируя, так называемый, Срединный Путь. И на этом пути, как завещает Д. Итигэлов, необходимо усердствовать в овладении безопасной практикой Десяти белых благих деяний - практикой нравственного поведения, основанной на воздержании от десяти пороков, которые подразделяются на связанные с телом, речью и умом. Выделяются следующие три порока тела: воровство, лишение жизни живого существа, сексуальные проступки; четыре порока речи: ложь, пу-

себе все отпечатки, оставленные человеком благими, неблагими мыслями и поступками в предыдущих рождениях и в настоящем.

27 Пустота (санскр. шуньята) - объяснение пустоты Будда Шакьямуни дал при втором повороте Колеса Учения. О том, что все явления пусты по своей природе, лишены самобытия описаны в текстах праджняпарамиты и в комментариях Нагарджуны и его последователей. 
стословие, злословие, грубость; три порока ума: зависть, злонамеренность, ложные взгляды.

Хамбо-ламе Д. Итигэлову удалось не только теоретически овладеть, но и на практике скрепить союзом метод и мудрость, т. е. объединить две составляющие - бодхичитту и воззрение, постигающее пустотность. Если бодхичитта - это наивысший, особенный аспект метода, то высшим из аспектов мудрости является воззрение, постигающее пустотность. Только соединив эти два аспекта, Итигэлов смог одновременно накопить собрания мудрости и заслуг; без этих двух собраний невозможно достичь состояния бодхисаттвы, будды. Эти две составляющие - наивысшие элементы, лежащие в основе буддийской эстетико-философской системы, которые сумел постичь и практически воплотить в реальной жизни Дашидоржи Итигэлов.

Шантидева в своей философской поэме «Бодхичарья-аватара» пишет:

Освободившись от привязанности и страха,

Бодхисаттва способен оставаться в сансаре ради тех,

Кто страдает из-за омраченности.

Таков плод постижения пустоты.

$$
[20, \text { c. I56] }
$$

XII Хамбо-лама Дашидоржи Итигэлов, объединив в своей личности три ключевых аспекта Пути просветления, - отречение, бодхичитту u воззрение, постигающее пустотность, - достигнув совершенных способностей, свойственных Бодхисаттвам и Буддам, все же принял решение остаться в сансаре ради блага всех шести живых существ. Это Его решение, и оно равнозначно подвигу, духовному подвигу.

В настоящее время Его духовный подвиг еще не может быть адекватно понят и оценен обычным человеческим разумом, так как наш разум действует на уровне относительной истины. В соответствии с коренными буддийскими текстами высшая истина не может быть познана разумом. В «Сутре о совершенной мудрости, рассекающей [тьму невежества], как удар молнии» (Ваджраччхедика-праджняпапамита-сутра) говорится: 
Высшая природа Будд,

Высшее тело духовных наставников

Не могут быть познаны разумом.

$$
\text { [13, c. 150] }
$$

Вместе с тем необходимо отметить, что Хамбо-лама Дашидоржи Итигэлов, как буддийский мыслитель, творческая личность и практикующий йогин, своим возвращением начал и ведет свой незримый диалог с нами, с людьми XXI в. Несомненно, «Завет» Д. Итигэлова представляет собой самодостаточную ценность, ибо данное произведение продолжает традицию, начатую в Индии Нагарджуной ${ }^{28}$, затем продолженный в Тибете Атишой ${ }^{29}$ и Цонкапой в цепи произведений класса лам-рим, т. е. «путеводителей», дарующих духовные наставления и нравственно-поведенческие ориентиры для достижения совершенного пробуждения. Безусловно, «Завет» Д. Итигэлова, написанный в поэтической форме в жанре послания, - это его прощальное заветное слово, его наказ, представляющий конечный результат его художественного творчества. И свою Жизнь, как в прошлом, так и в настоящем, Он представил как Творчество - вдохновляющее, обогащающее, расширяющее. Ему удалось приоткрыть окно в «другой Мир», подвигая современное общество к новым духовным поискам и находкам.

\section{Список литературы}

I Андросов В.П. Учение Нагарджуны о Срединности: исслед. и пер. с санскр. «Толкования Коренных строф о Срединности [называемого] Бесстрашным [опровержением догматических воззрений]» (Муламадхъямака-вритти Акутобхайя). М.: Восточная литература, 2006. 435 с.

\footnotetext{
28 Нагарджуна - крупнейший буддийский классик, основатель философской школы мадхъямака, живший в Индии на рубеже нашей эры. Важнейшим из его трудов является «Муламадхъямака-карика» (Коренные стихи о срединности), благодаря которому произошел своего рода переворот в буддизме, ибо был пролит свет на глубинный смысл учения Будды о пустотности.

29 Атиша (982-1054) - великий буддийский мастер, приглашенный в Тибет из Индии для возрождения буддизма. Основатель традиции кадам и автор первого текста лам-рим «Светильник на пути к пробуждению».
} 
Андросов В.П. Буддийская классика Древней Индии. Слово Будды и трактаты Нагарджуны в переводах с палийского, санскритского и тибетского языков с комментариями. М.: Алмазный путь, 2010. 512 c.

Арья Шура. Гирлянда джатак, или Сказания о подвигах Бодхисаттвы / пер. с санскрита А.П. Баранникова и О.Ф. Волковой. М.: Восточная литература, 2000. 285 с.

Балданмаксарова Е.Е. Бурятская поэзия XX века: истоки, поэтика жанров. М.: МГУ, 2002. 273 c.

Балданмаксарова Е.Е. «Кавьядарша» Дандина как основа развития теории поэзии монгольских народов // Международный конгресс востоковедов ICANAS XXXVII. М.: Ин-т востоковедения РАН, 2004. T. 2. С. 74I-744.

Балданмаксарова Е.Е. Развитие теории поэзии монгольских народов: индо-тибетская поэтическая традиция // История национальных литератур. Перечитывая и переосмысливая / отв. ред. К.К. Султанов. М.: ИМЛИ РАН, 2015. Вып. V. C. $244^{-255}$.

Будон Ринчендуб. История буддизма (Индия, Тибет) / Р. Будон; пер. с тибетск. Е.Е. Обермиллера, пер. с англ. А.М. Донца. СПб.: Евразия, І999. 366 с.

Васильева Я.Д. Пандито Хамбо Лама Итигэлов. Смерти нет. Улан-Удэ: ООО «НоваПринт», 2013. 264 с.

Восточная поэтика. Тексты. Исследования. Комментарии / отв. ред. П.А. Гринцер. M., I996. 326 c.

Владимириов Б.Я. Badhicariyavatara, Cantideva / монг. перевод Chos-kyi Nod-zera. I. Текст. (Boblioteca Budhica, XXVIII). Л.: Изд-во АН СССР, І929. I85 с.

Гадамер Г.-Г. Истина и метод: Основы философской герменевтики. Пер. с нем. / общ. ред. и вступ. статья Б.Н. Бессонова. М., І988. 302 с.

2 Далай-лама XIV Тензин Гьящо. Комментарий на «37 практик Бодхисаттвы» / пер. с англ. и тиб. М.: Открытый мир, 2006. 240 с.

3 Далай-лама. Вспышка молнии во мраке ночи. Краткий комментарий к «Бодхичарья-аватаре» Шантидевы / пер. с англ. и общ. ред. Ю. Жиронкиной; науч. ред. Б. Загуменнов. М.: Фонд «Сохраним Тибет», 2016. І76 c.

4 Далай-лама. Совершенная мудрость. Комментарий к девятой главе «Бодхичарья-аватары» Шантидевы / пер. с англ. и общ. ред. Ю. Жиронкиной; науч. ред. Б. Загуменнов. М.: Фонд «Сохраним Тибет», 20I6. 232 с.

Дхаммапада / пер. с пали В.Н. Топорова. М.: Согласие, 2003. I89 с. Сутра сердца. Учения о Праджняпарамите. Элиста: Океан мудрости, 2008. 215 c. Феномен XII Хамбо-ламы Итигэлова. Материалы II конференции. 26-27 июня 2009 г. Улан-Удэ: Иволгинский дацан, 2009. I89 с.

Чандракирти. Введение в Мадхъямику / пер. А. Донца. СПб.: Евразия, 2004. 244 c.

9 Чимитдоржин Д.Г. Пандито Хамбо-ламы. I764-20го. Улан-Удэ: «Печатный дворъ», 201О. I92 с. 
20 Шантидева. Путь Бодхисаттвы (Бодхичарья-аватара) / пер. и общ. ред. Ю. Жиронкиной; науч. ред. Б. Загуменнов, 2-е изд., испр. и доп. М.: Фонд «Сохраним Тибет», 20I2. 280 c.

\section{References}

I Androsov V.P. Uchenie Nagardzhuny o Sredinnosti: issled. i per. s sanskr. "Tolkovanija Korennyh strof o Sredinnosti [nazyvaemogo] Besstrashnym [oproverzheniem dogmaticheskih vozzrenij]" (Mulamadhjamaka-vritti Akutobhajja) [Nagarjuna’s doctrine of the Mediality: studies trans. from Sanskrit "Interpretation of the core phrases on Mediality called Fearless; refutation of dogmatic views]. Moscow, Vostochnaja literature Publ., 2006. 435 p. (In Russ.) Androsov V.P. Buddijskaja klassika Drevnej Indii. Slovo Buddy i traktaty Nagardzhun $v$ perevodah s palijskogo, sanskritskogo i tibetskogo jazykov s kommentarijami [Classic Buddhism of Ancient India. Buddha's word in Nagarjuna treatise and in translations from Pali, Sanskrit, and Tibetan languages with commentaries]. Moscow, Almaznyj put' Publ., 20IO. 5I2 p. (In Russ.)

3 Ar'ja Shura. Girljanda dzhatak, ili Skazanija o podvigah Bodhisattvy [The garland djatak, or the Narrative about Bodhisatvva's deads], trans. from Sanskrit A.P. Barannikov, O.F. Volkova. Moscow, Vostochnaja literature Publ., 2000. 285 p. (In Russ.) Baldanmaksarova E.E. Burjatskaja pojezija XX veka: istoki, pojetika zhanrov [Buryar 2oth century poetry: origins, poetics of genres]. Moscow, MGU Publ., 2002. 273 p. (In Russ.)

5 Baldanmaksarova E.E. “Kav’jadarsha” Dandina kak osnova razvitija teorii pojezii mongol'skih narodov [Dandin's Kavjadasrsha as the basics of the poetic theory of Mongolian nations]. Mezhdunarodnyj kongress vostokovedov ICANAS XXXVII [International Congress of Oriental Studies]. Moscow, Institut vostokovedenija RAN Publ., 2004, vol. 2, pp. 74I-744. (In Russ.)

6 Baldanmaksarova E.E. Razvitie teorii pojezii mongol'skih narodov: indo-tibetskaja pojeticheskaja tradicija [The development of poetic theory in Mongolia: Indo-Tibet poetical tradition]. Istorija nacional'nyh literatur. Perechityvaja i pereosmyslivaja [The history of national literatures. Rereadings and reinterpretations], ed. K.K. Sultanov. Moscow, IMLI RAN Publ., 20I5, issue V, pp. 244-255. (In Russ.) Budon Rinchendub. Istorija buddizma (Indija, Tibet) [The history of Buddhism (India, Tibet)], R. Budon; trans. from Tibetan E.E. Obermiller, trans. from English A.M. Donc. St. Petersburg, Evrazija Publ., I999. 366 p. (In Russ.) Vasil'eva Ja.D. Pandito Hambo Lama Itigjelov. Smerti net [Pandito Hambo Lama Itigjelov. There’s no death]. Ulan-Udje, OOO “NovaPrint” Publ., 20I3. 264 p. (In Russ.)

9 Vostochnaja pojetika. Teksty. Issledovanija. Kommentarii [Oriental poetics. Studies. Commentaries], ed. P.A. Grincer. Moscow, IMLI RAN Publ., I996. 326 p. (In Russ.) 
Io Vladimircov B.Ja. Badhicariyavatara, Cantideva [Bodhicaryavatara, Sāntideva], trans. from Mongolian by Chos-kyi Nod-zera. I. Text. (Boblioteca Budhica, XXVIII). Leningrad, Izd-vo AN SSSR Publ., I929. I85 p. (In Russ.)

II Gadamer G.-G. Istina i metod: Osnovy filosofskoj germenevtiki [Truth and method: Foundations of Philosophical Hermeneutics]: trans. from German, ed. and intro. B.N. Bessonov. Moscow, I988. 302 p. (In Russ.)

I2 Dalaj-lama XIV Tenzin G'jaco. Kommentarij na "37 praktik Bodhisattvy” [Commentaries to the 37 Practics of Bodhisattva], trans. from English and Tibetan. Moscow, Otkrytyj mir Publ., 2006. 240 p. (In Russ.)

I3 Dalaj-lama. Vspyshka molnii vo mrake nochi. Kratkij kommentarij $k$ "Bodhichar'jaavatare" Shantidevy [Flash of the lightning in the darkness of the night. Brief commentary to Bodhi Chaja-avatary by Shantideva], trans. from English and ed. Ju. Zhironkina, ed. B. Zagumennov. Moscow, Fond “Sohranim Tibet” Publ., 20I6. I76 p. (In Russ.)

I4 Dalaj-lama. Sovershennaja mudrost'. Kommentarij $k$ devjatoj glave "Bodhichar'jaavatary" Shantidevy [Modern wisdom. Commentaries to the $9^{\text {th }}$ chapter of Bodhi Chaja-avatary by Shantideva], trans. from English and ed. Ju. Zhironkina, scientific ed. B. Zagumennov. Moscow, Fond “Sohranim Tibet” Publ., 20I6. 232 p. (In Russ.)

I5 Dhammapada [Dhammapada], trans. from Pali V.N. Toporov. Moscow, Soglasie Publ., 2003. I89 p. (In Russ.)

I6 Sutra serdca. Uchenija o Pradzhnjaparamite [Surta serdca. The doctrine of Pradjaparamita]. Jelista, Okean mudrosti Publ., 2008. 215 p. (In Russ.)

I7 Fenomen XII Hambo-lamy Itigjelova. Materialy II konferencii. 26-27 ijunja $2009 \mathrm{~g}$. [The phenomenon of XII Hambo-lamy Itigjelov. Conference proceedings]. Ulan-Udje, Ivolginskij dacan Publ., 2009. I89 p. (In Russ.)

I8 Chandrakirti. Vvedenie v Madhjamiku [Introduction into Madjamuka], trans. A. Donc. St. Petersburg, Evrazija Publ., 2004. 244 p. (In Russ.)

I9 Chimitdorzhin D.G. Pandito Hambo-lamy. I764-20Io [Pandito Hambo-lamy]. Ulan-Udje, "Pechatnyj dvor" Publ., 20Io. I92 p. (In Russ.)

20 Shantideva. Put' Bodhisattvy (Bodhichar'ja-avatara) [The way of Bodhisattva], trans. and ed. Ju. Zhironkina, ed. B. Zagumennov, $2^{\text {nd }}$ revised ed. Moscow, Fond "Sohranim Tibet” Publ., 20I2. 280 p. (In Russ.) 